\title{
Energy storage system in traction vehicle
}

\author{
Maciej Wieczorek ${ }^{1, *}$, and Mirosław Lewandowski ${ }^{1}$ \\ ${ }^{1}$ Warsaw University of Technology, Institute of Electric Power Engineering, Electric Traction Division, \\ ul. Koszykowa 75, 00-662, Warsaw, Poland
}

\begin{abstract}
The paper compares three different types of energy storage system (ESS) in a tramway. It was assumed that the tram has to travel without catenary for $5 \mathrm{~km}$. Two homogeneous energy storage systems were designed to provide energy for the ride: the first made of lithium-ion batteries and the second made of supercapacitors. The third solution is a hybrid ESS (HESS) composed of both of the aforementioned technologies. The comparison was made in terms of weight, price and power consumption when driving with and without a catenary. Using a well-fitted energy management strategy, 50\% lower HESS mass was achieved compared to the homogeneous ESSes. The estimated price of the HESS is $29 \%$ lower than the battery ESS and 59\% from the supercapacitor ESS. A comparison of the energy consumption of the tram with and without the ESS is also presented, depending on the amount of energy absorbed by other vehicles on the same power section. It follows that the use of the ESS allows for significant energy savings for driving with the catenary.
\end{abstract}

\section{Introduction}

Energy storage systems (ESS) are increasingly being used in electric traction as a means of more effectively utilizing regenerative braking energy which, in case of rail vehicles, is a significant part of energy taken from power system because of their large mass, or to maintain proper voltage [1]. For this purpose, supercapacitors are most often used because of their high specific strength.

In some applications a tram is required to be able to travel part of the route without power supply. This situation can occur in e.g. historic parts of towns where it is impossible to set up a traction network. A supercapacitor ESS would have to be much bigger to provide the energy. That would translate into a high price of the ESS. The use of a lithium-ion battery will allow to achieve the energy needed for the travel. However, due to low specific power of the lithium cells it is necessary to oversize the ESS in terms of stored energy. This will also translate into a high price of the device.

The solution to the optimum ESS selection is the use of a hybrid ESS (HESS) consisting of lithium batteries and supercapacitors. HESS is a matter widely discussed in literature. Especially when electric vehicles are considered [2], [3]. HESS effectiveness is, however, strongly dependent on the energy management strategy EMS used.

HESS sizing and EMS optimization for an electric car was presented in [4], [5]. Similar topic was also addressed to urban vehicles such as buses in [6-8] and tramway in [9]. HESS's profitability analysis was performed [10].
This article focuses on the selection of ESS to tramway, which must move without catenary for a short distance and compare different solutions of the ESS in terms of mass, price and energy consumption.

\section{Trams ESS configurations}

It was assumed that the ESS in tram should enable it to drive for $5 \mathrm{~km}$ without catenary. To size the ESS the method presented in [11] was adopted. For calculating the initial cost of ESSes the prices of cells were taken from one distributor. The total price of energy storage pack was estimated on the basis of modules and packs assembly cost presented in BCG report [12]. The mass of the components of the packs was assumed at $24 \%$ of the cell mass based on the data presented in [13].

In the case of a homogeneous battery ESS, the maximum power is the decisive factor for the final size of the battery pack. Therefore, the stored energy is much higher than the demand. Less than $5 \%$ of capacity is used. On the other hand, this has a positive effect on the battery life since it is strictly dependent on the depth of discharge [14]. Nevertheless, such a large oversizing of battery inflates the price and weight (Table 1).

Sizing a supercapacitor ESS should be based primarily on the energy capacity of the package. Due to the significantly higher power density of supercapacitors than lithium batteries, the power of the supercapacitor will be much higher than necessary. In this case, it also results in a high price and the weight of the ESS.

The process of sizing a HESS requires simultaneous design of EMS. The Gamma Based Strategy described in [4] was used in the analysis because of its simplicity and the fast process of selecting the coefficients that shape

* Corresponding author: maciej.wieczorek@ee.pw.edu.pl 
the power of individual devices. It also allows for effective use of supercapacitor capacity.

Power demand of a tram is largely predictable, due to fixed route and minor interaction with traffic. This makes it possible to avoid oversizing ESS. The analysis carried out in this paper has included the tram ride in the UITP sort2 (easy urban) cycle. An example of the power of the devices in HESS is shown in Figure 1. The detailed parameters of the trays are given in Table 1. Red colour indicates the parameters that have the decisive influence on the final size of the pack.

\section{ESS models and simulation}

The energy ESS installed on board of a vehicle, besides enabling drive without catenary, should accumulate regenerative braking energy. In situations where other trams on the same power section are unable to receive the braking energy, it is dissipated as heat. Therefore, the use of an ESS in a tram should reduce energy consumption. The EMS in HESS differs for driving with the catenary (Fig. 2) and without it (Fig. 1). During nocatenary operation, the supercapacitor provides high power during acceleration due to low maximum power of the battery. It is important not to discharge the supercapacitor prematurely as this would result in a power shortage. Therefore, during regenerative braking and at standstill, the supercapacitor is recharged from the battery.

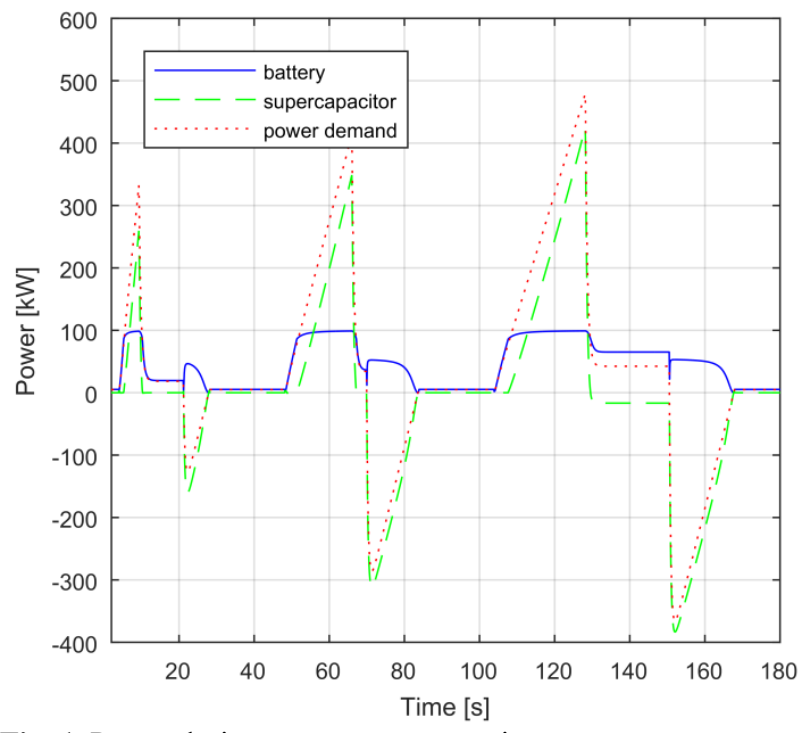

Fig. 1. Power during no-catenary operation.

While driving with catenary, the tram does not use the battery pack of HESS. Only supercapacitors work. The analysis assumes that all the regenerative braking energy is accumulated by the ESS and then used for acceleration. The strategy of using ESS when traveling with catenary is identical for trams with homogeneous ESS.
Table 1. ESSes parameters.

\begin{tabular}{|c|c|c|c|}
\hline & $\begin{array}{l}\text { BATT } \\
\text { TRAM } \\
\end{array}$ & $\begin{array}{c}\text { HESS } \\
\text { TRAM } \\
\end{array}$ & $\begin{array}{c}\text { SC } \\
\text { TRAM } \\
\end{array}$ \\
\hline \multicolumn{4}{|c|}{ VEHICLE } \\
\hline $\begin{array}{l}\text { total vehicle mass (without } \\
\text { passengers) }[\mathrm{kg}]\end{array}$ & 45983 & 44768 & 45946 \\
\hline motor power $[\mathrm{kW}]$ & 200 & 200 & 200 \\
\hline $\begin{array}{l}\text { reference autonomy in UITP } \\
\text { sort } 2 \text { (easy urban) }[\mathrm{km}]\end{array}$ & 5 & 5 & 5 \\
\hline $\begin{array}{l}\text { calculated autonomy in UITP } \\
\text { sort } 2 \text { (easy urban) }[\mathrm{km}]\end{array}$ & 120 & 23 & 5 \\
\hline DC voltage $[\mathrm{V}]$ & 600 & 600 & 600 \\
\hline auxiliary load $[\mathrm{kW}]$ & 5 & 5 & 5 \\
\hline \multicolumn{4}{|c|}{$\begin{array}{r}\text { BATTERY MODULE } \\
\end{array}$} \\
\hline manufacturer & \multicolumn{2}{|c|}{ HEADWAY } & - \\
\hline chemistry & LFP & LFP & - \\
\hline $\begin{array}{l}\text { number of cells connected in } \\
\text { series }\end{array}$ & 186 & 186 & 0 \\
\hline $\begin{array}{l}\text { number of cells connected in } \\
\text { parallel }\end{array}$ & 30 & 6 & 0 \\
\hline stored energy $[\mathrm{kWh}]$ & 178.5 & 35.71 & 0 \\
\hline cells mass $[\mathrm{kg}]$ & 1841 & 368.2 & 0 \\
\hline module mass $[\mathrm{kg}]$ & 2283 & 456 & 0 \\
\hline nominal voltage $[\mathrm{V}]$ & 595.2 & 595.2 & 0 \\
\hline cells cost $[\$]$ & 117180 & 23436 & 0 \\
\hline module cost $[\$]$ & 164052 & 32810 & 0 \\
\hline $\begin{array}{l}\text { nominal power for } 2000 \\
\text { cycles }(\mathrm{I}=0.5 \mathrm{C})[\mathrm{W}]\end{array}$ & 89280 & 17856 & 0 \\
\hline Pmax_in & 357120 & 71424 & 0 \\
\hline Pmax_out & 535680 & 107136 & 0 \\
\hline \multicolumn{4}{|c|}{ SUPERCAPACITOR MODULE } \\
\hline manufacturer & - & \multicolumn{2}{|c|}{ MAXWELL } \\
\hline $\begin{array}{l}\text { number of cells connected in } \\
\text { series }\end{array}$ & 0 & 222 & 222 \\
\hline $\begin{array}{l}\text { number of cells connected in } \\
\text { parallel }\end{array}$ & 0 & 4 & 16 \\
\hline nominal voltage $[\mathrm{V}]$ & 0 & 599.4 & 599.4 \\
\hline capacitance $[\mathrm{F}]$ & 0 & 54 & 216 \\
\hline cells mass $[\mathrm{kg}]$ & 0 & 453 & 1811 \\
\hline module mass $[\mathrm{kg}]$ & 0 & 561 & 2246 \\
\hline cells cost $[\$]$ & 0 & 53280 & 213120 \\
\hline module cost $[\$]$ & 0 & 74592 & 298368 \\
\hline stored energy [Wh] & 0 & 2699 & 10798 \\
\hline usable energy [Wh] & 0 & 2024 & 8098 \\
\hline nominal power $[\mathrm{kW}]$ & 0 & 503.5 & 2014.0 \\
\hline maximum power $[\mathrm{kW}]$ & 0 & 2672 & 10688 \\
\hline \multicolumn{4}{|c|}{ DC/DC CONVERTERS } \\
\hline number of converters & 1 & 2 & 1 \\
\hline cost of converters & 15000 & 20000 & 15000 \\
\hline mass of converters & 100 & 150 & 100 \\
\hline \multicolumn{4}{|c|}{$\begin{array}{l}\text { ENERGY STORAGE SUMMARY } \\
\end{array}$} \\
\hline $\begin{array}{l}\text { Total energy storage system } \\
\text { mass }[\mathrm{kg}]\end{array}$ & 2383 & 1168 & 2346 \\
\hline $\begin{array}{l}\text { Initial energy storage system } \\
\text { cost [\$] }\end{array}$ & 179052 & 127402 & 313368 \\
\hline
\end{tabular}




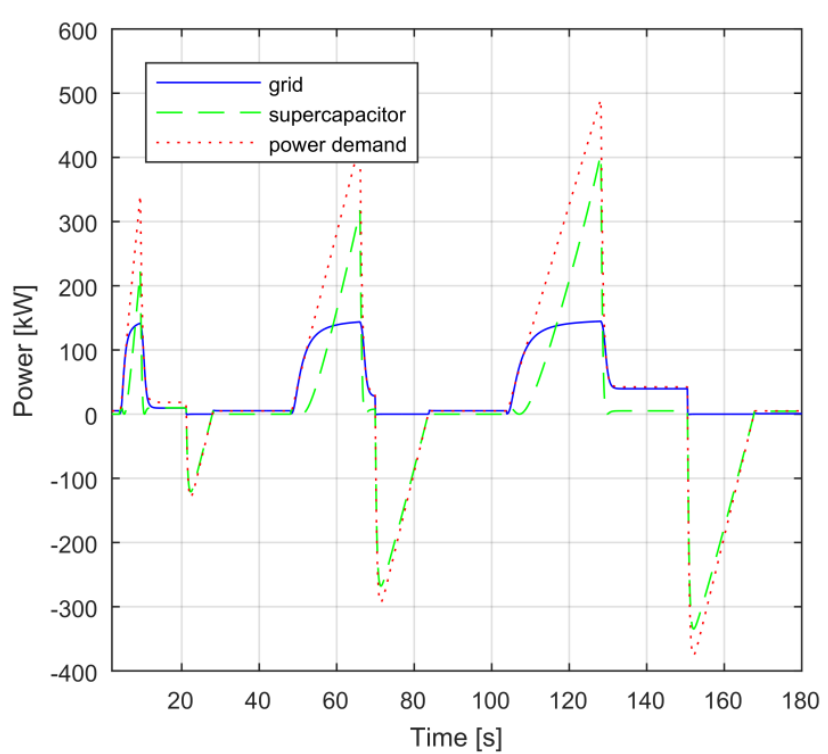

Fig. 2. Power during operation with catenary.
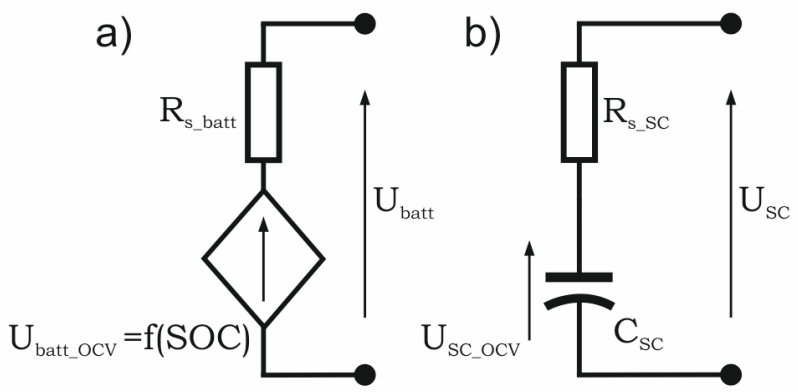

Fig. 3. Equivalent circuit of a) lithium battery and b) supercapacitor.

In order to estimate the energy consumption, simulations of each tramway were performed. The energy storage device models used here affect the energy consumption estimate. Thus, the most important parameters for the calculation are the source voltage and the internal resistance. Therefore, a series models have been used, i.e. of the voltage source and resistance for the battery (Fig. 3a) and of the RC model for the supercapacitor (Fig. 3b).

The internal resistance and capacity of lithium batteries and supercapacitors varies depending on a number of factors, such as state of charge (SOC), value and direction of load current, temperature, and state of health $(\mathrm{SOH})$ [14-18]. These changes, varying from $70 \%$ to $200 \%$ of rated values given by manufacturers [14], [19-22] have minor influence on trams energy consumption comparison. Therefore in the analysis they were neglected. a)
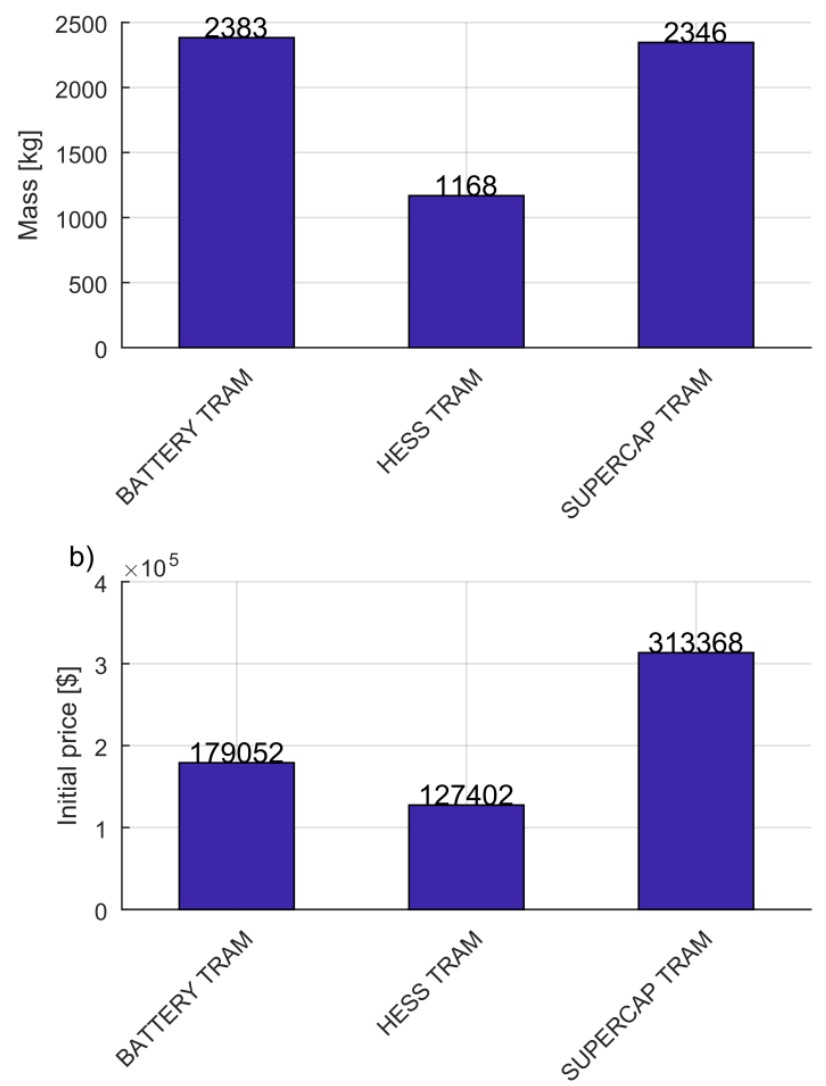

Fig. 4. Comparison of a) mass and b) prices of each ESS.

\section{Results and discussion}

Fig. 4a shows masses of ESSes in described vehicles. Masses of the homogeneous ESSes are similar. Comparing with them the HESS has $50 \%$ lower mass. Compared to the total weight of the tram, this difference seems small, but it has an impact on energy consumption. More interesting result from the point of view of both the producer and buyer is the price of the energy storage. This is highest in the case of the supercapacitor (Fig. 4b). The cheapest solution is the HESS. It is $29 \%$ cheaper than the battery ESS and 59\% cheaper than the supercapacitor ESS.

The analysis compares the energy consumption of the proposed trams. Fig. 5a shows the energy consumption per kilometre when driving without catenary. Differences are small. The smallest energy consumption was achieved by a vehicle with a supercapacitor. This is because this ESS has the lowest internal resistance. 
a)

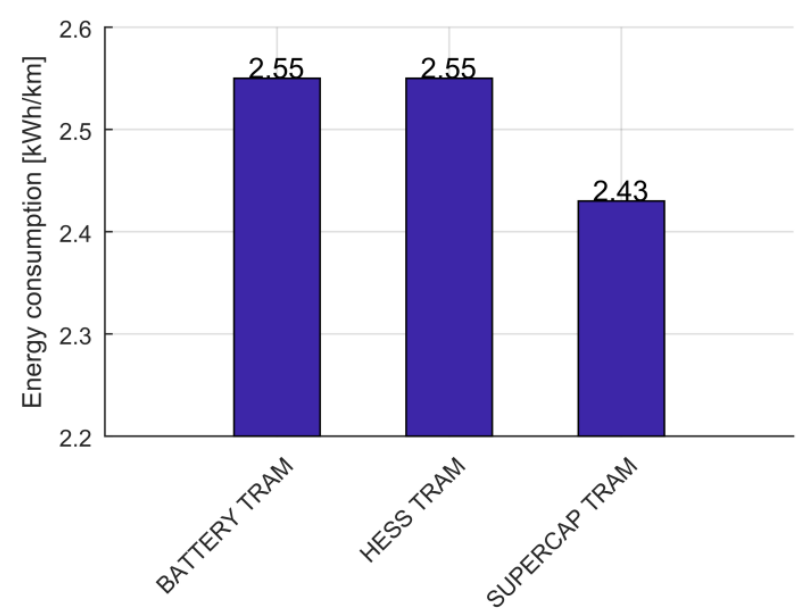

b)

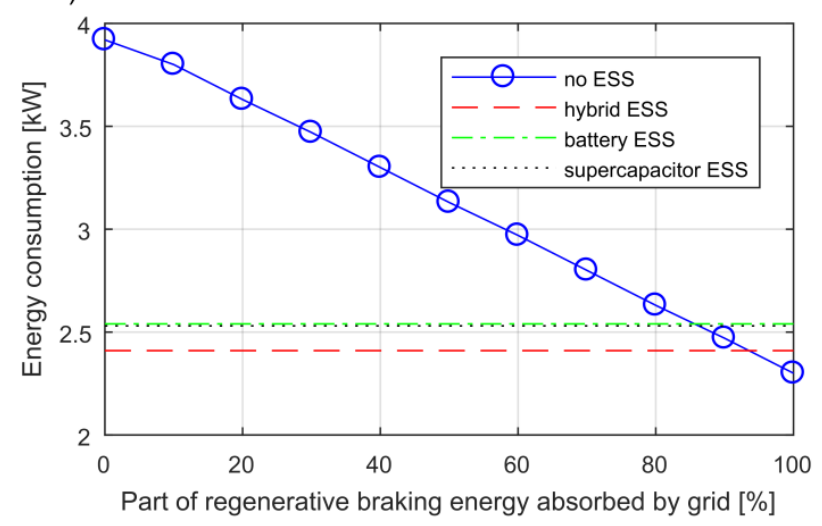

Fig. 5. Energy consumption comparison for a) operation without catenary and b) operation with catenary.

Fig. 5b shows the energy consumption when traveling with the catenary. The results for trams with different ESS are compared to the energy consumption of a tram without ESS, whose braking energy is received by other vehicles at the power section. It can be seen that even in the case of driving with a grid power supply, the energy storage can significantly reduce energy consumption. The energy consumption of the tram without ESS was lower when other vehicles received more than $90 \%$ of its braking energy.

\section{Conclusions}

Basing on the results presented in the paper it can be stated that the use of a hybrid energy storage system with a well-fitted energy management strategy allows to achieve much better parameters than the uniform tanks. This applies both to energy and economic parameters.

\section{References}

1. A. Szelag, Wplyw napięcia $w$ sieci trakcyjnej 3 $k V D C$ na parametry energetyczno-trakcyjne zasilanych pojazdów (Instytut Naukowo-
Wydawniczy SPATIUM, 2013) [In Polish]

2. X. Luo, J. Wang, M. Dooner, and J. Clarke, Overview of current development in electrical energy storage technologies and the application potential in power system operation, Appl. Energy, 137, 511-536 (2015)

3. R. Hemmati and H. Saboori, Emergence of hybrid energy storage systems in renewable energy and transport applications - A review, Renew. Sustain. Energy Rev., 65, 11-23 (2016)

4. M. Wieczorek and M. Lewandowski, $A$ mathematical representation of an energy management strategy for hybrid energy storage system in electric vehicle and real time optimization using a genetic algorithm, Appl. Energy, 192, 222-233 (2017)

5. A. Castaings, W. Lhomme, R. Trigui, and A. Bouscayrol, Comparison of energy management strategies of a battery/supercapacitors system for electric vehicle under real-time constraints, Appl. Energy, 163, 190-200 (2016)

6. V. I. Herrera, A. Milo, H. Gaztañaga, and H. Camblong, Multi-objective Optimization of Energy Management and Sizing for a Hybrid Bus with dual Energy Storage System, 2016 IEEE Vehicle Power and Propulsion Conference (VPPC) (2016).

7. Z. Song, H. Hofmann, J. Li, X. Han, and M. Ouyang, Optimization for a hybrid energy storage system in electric vehicles using dynamic programing approach, Appl. Energy, 139, 151162 (2015)

8. Z. Song, J. Li, X. Han, L. Xu, L. Lu, M. Ouyang, and H. Hofmann, Multi-objective optimization of a semi-active battery/supercapacitor energy storage system for electric vehicles, Appl. Energy, 135, 212-224 (2014)

9. V. Herrera, A. Milo, H. Gaztañaga, I. EtxeberriaOtadui, I. Villarreal, and H. Camblong, Adaptive energy management strategy and optimal sizing applied on a battery-supercapacitor based tramway, Appl. Energy, 169, 831-845 (2016)

10. D. Zhu, S. Yue, S. Park, Y. Wang, N. Chang, and M. Pedram, Cost-effective design of a hybrid electrical energy storage system for electric vehicles, Proc. 2014 Int. Conf. Hardware/Software Codesign Syst. Synth. CODES '14, 1-8 (2014)

11. R. Sadoun, N. Rizoug, P. Bartholomeus, and P. Le Moigne, Optimal sizing of hybrid supply for electric vehicle using Li-ion battery and supercapacitor, Int. Rev. Electr. Eng., 9(2), 332340 (2014) 
12. The Boston Consulting Group, Focus Batteries for Electric Cars, Outlook, 1, 1-18 (2010)

13. P. Miller, Automotive Lithium-ion Batteries, Johnson Matthey Technol. Rev., 59(1), 4-13 (2015)

14. N. Omar, M. Abdel, Y. Firouz, J. Salminen, J. Smekens, O. Hegazy, H. Gaulous, G. Mulder, P. Van Den Bossche, and T. Coosemans, Lithium iron phosphate based battery - Assessment of the aging parameters and development of cycle life model, Appl. Energy, 113, 1575-1585 (2014)

15. M. A. Danzer, V. Liebau, and F. Maglia, Aging of lithium-ion batteries for electric vehicles (Elsevier Ltd., 2015)

16. K. Jalkanen, J. Karppinen, L. Skogström, T. Laurila, M. Nisula, and K. Vuorilehto, Cycle aging of commercial NMC/graphite pouch cells at different temperatures, Appl. Energy, 154, 160-172 (2015)

17. N. Omar, Y. Firouz, H. Gualous, J. Salminen, T. Kallio, J. M. Timmermans, T. Coosemans, P. Van den Bossche, and J. Van Mierlo, 9-Aging and degradation of lithium-ion batteries (Elsevier Ltd., 2015)
18. M. Lewandowski, M. Orzyłowski, Fractionalorder models: The case study of the supercapacitor capacitance measurement, Bull. Polish Acad. Sci. -Technical Sci., 65(4), 449-457 (2017)

19. D. Anseán, M. González, M. Ieee, J. C. Viera, M. Ieee, J. C. Antón, and C. Blanco, Evaluation of LiFePO 4 batteries for Electric Vehicle applications, IEEE Trans. Ind. Appl., 51(2), 1855-1863 (2015)

20. H. Gualous, R. Gallay, M. Al Sakka, A. Oukaour, B. Tala-Ighil, and B. Boudart, Calendar and cycling ageing of activated carbon supercapacitor for automotive application, Microelectron. Reliab., 52(9-10), 2477-2481 (2012)

21. P. Kreczanik, P. Venet, A. Hijazi, and G. Clerc, Study of supercapacitor aging and lifetime estimation according to voltage, temperature, and RMS current, IEEE Trans. Ind. Electron., 61(9), 4895-4902 (2014)

22. D. Yan, L. Lu, Z. Li, X. Feng, M. Ouyang, and F. Jiang, Durability comparison of four different types of high-power batteries in HEV and their degradation mechanism analysis, Appl. Energy, 179, 1123-1130 (2016) 